\title{
Hal Penting dalam kinerja Sebuah Perusahaan (Firm Performance)
}

Nama : Afan Miftakhul Huda

Email : afanmiftakhulhuda@gmail.com

Diantara grup dalam suatu organisasi / perusahaan, salah satu yang sangat penting adalah tim manajemen puncak (TMT). Manajer puncak sering bekerja secara kolektif sebagai koalisi yang dominan karena mengelola perusahaan adalah efek bersama secara umum. Sehingga kinerja perusahaan tentu menajdi tanggung jawab secara bersama dari sebuah perusahaan. Yang dimana kinerja perusahaan relatif mengingat bahwa kompensasi eksekutif sering dikaitkan dengan kinerja perusahaan dan organisasi berusaha untuk mencapai tingkat yang diinginkan (Harris dan Bromiley, 2007).

Hasil penelitian menunjukkan bahwa strategi penghematan meningkatkan kinerja perusahaan. Kinerja perusahaan diukur dengan menggunakan Return on Assets (ROA) dan Tobin's Q (Q). yang dimana penelitian tersebut menggunakan rasio pengembalian aset (ROA) untuk menangkap kinerja buku akuntansi, dan Tobin's Q yang dimana fungsinya adalah untuk menangkap kinerja berbasis pasar Yang dimana dalam penelitian tersebut juga mengikutib dari pernyataan Ung et al. (2018), yang dimana disebutkan bahwa ROA adalah rasio EBIT terhadap total aset, dan Tobin's q adalah rasio dari total nilai pasar perusahaan tertentu dengan biaya penggantian total asetnya. Jadi apabila perusahaan tersebut hemat dan mengembalikan asetnya lebih besar maka kinerja perusahaan dianggap bagus.

Yang dimana dari beberapa sumber dapat disimpulkan bahwa kinerja perusahaan dapat di ukur sama seperti point ketiga dari teori (Delery dan Doty, 1996) yang bernunyi : "Penilaian kinerja mengacu pada sejauh mana sistem penilaian organisasi berorientasi pada hasil. Penilaian kinerja diukur dengan menggunakan dua item yang meliputi: "Penilaian kinerja didasarkan pada hasil yang objektif dan dapat diukur".

Hasil dari rangkuman yang saya dapatkan yaitu teori kontingensi dan pandangan berbasis sumber daya sebagai teori yang mendasari untuk mendukung hipotesis. Karena studi ini membahas tentang dampak TT (turbulensi teknologi) informasi pada hubungan antara SO (orientasi strategis) dan FP (kinerja perusahaan), tinjauan tentang teori kontingensi dan pandangan berbasis sumber daya secara singkat membahas untuk menggambarkan signifikansinya. Teori kontingensi bertujuan untuk memahami bagaimana perusahaan menyelaraskan kinerja yang diharapkan dengan lingkungan bisnis internal dan eksternal (Homburg et al., 2012). Teori ini memandang bahwa lingkungan eksternal merupakan determinan utama FP. Sebagai organisasi, perusahaan menerima pengaruh lingkungan bisnis. Penelitian ini menggunakan metode kuantitatif dengan desain penampang. Analisis informasi bersumber dari daftar kuesioner yang disebarkan melalui pendekatan random sampling untuk memperoleh tingkat tanggapan yang maksimal. Desain kuesioner yang diadaptasi dari beberapa literatur bertujuan untuk mendapatkan informasi yang akurat dari responden. Ukuran SO diadaptasi dari Bradley et al. (2011), sedangkan TT diadaptasi dari Zhang dan Duan (2010). 
Keunggulan kompetitif mengacu pada kemampuan perusahaan untuk mencapai kinerja yang lebih besar dari pesaing mereka (Porter, 1998). Dalam lingkungan yang sangat dinamis, perusahaan membutuhkan adaptasi berbasis pengalaman untuk menciptakan keunggulan kompetitif (Schilke, 2014). Ketika lingkungan pasar yang kompleks berubah dengan cepat dan keunggulan kompetitif secara karakteristik tidak berkelanjutan, sumber daya wirausaha diakui sebagai konstruksi yang berguna untuk memahami kemampuan perusahaan untuk mencapai lintasan kinerja yang hebat sementara yang lain gagal (Covin dan Lumpkin, 2011). Keunggulan kompetitif yang berkelanjutan mengacu pada penciptaan nilai di mana perusahaan mengejar inovasi tinggi dengan mendorong persaingan. Namun, pembelajaran antar organisasi mungkin gagal dari orientasi pemasaran karena kurangnya diferensiasi kompetitif, kepuasan dengan status quo dan informasi asimetris pelanggan. Perusahaan mungkin mempercayai peran orientasi pasar, tetapi dalam praktiknya, mereka mungkin mengalami kurangnya kemampuan untuk mencapai kinerja yang ditargetkan melalui orientasi pasar. Penelitian ini menggunakan data primer yang diperoleh dari survei. Populasi yang ditargetkan adalah industri manufaktur dimana Kementerian Perindustrian dan Perindustrian telah menyediakan database industrinya. Berdasarkan database, penyebaran kuisioner melibatkan beberapa surveyor untuk mendapatkan konfirmasi dari responden apakah perusahaan menyelenggarakan kerjasama antar organisasi pada penelitian dan pengembangan. Untuk mendapatkan objektivitas data, pengumpulan data dilakukan dengan metode self-administrative respond, dimana surveyor tidak terlibat dalam pengisian kuesioner. Setelah penyaringan data, kumpulan data akhir memiliki 280 tanggapan (ukuran sampel), yang berasal dari manajer yang secara sukarela mendeskripsikan organisasinya.

Jadi dapat dapat disimpulkan bahwa perusahaan ini memiliki perbedaan yaitu:

1. Bahwa ditahun 2016 dalam penelitian ini penulis menggunakan penelitian kuantitatif, karena data yang diperoleh nantinya berupa angka. Dari angka yang diperoleh akan dianalisis lebih lanjut dalam analisis data. Penelitian ini terdiri atas dua variabel, yaitu Non Performing Financing (NPF) sebagai variabel bebas (independent) dan Return On Asset (ROA) sebagai variabel terikat (dependent). Sedangkan ditahun 2019 menggunakan data primer yang dimana didapatkan dari perusahaan atau database suatu perusahaan yang dimana data didapat dari perusahaan bukan secara alngsung dari responden. Sehingga data yang duhasilkan tidak seakurat dengan tahun 2016.

2. Selain itu juga hasil data yang ada juga berbeda misalkan ditahun 2016 data lebih banyak dominan angka sedangkan di tahun 2019 data cenderung lebih ke skala saja misalnya skala 1-7 menyatakan puas sampai kurang puas. Dan dilihat dari persamaanya maka disimpulkan bahwa perusahaan ingin menjadi lebih baik dengan mengikuti inovasi atau trend pasar yang sedang berkembang meskipun berbeda cara penelitian dan cara pengumpulan datanya. Sehingga kedua perusahaan ini dipastikan ingin mengembangkan produknyalebih baik lagi dengan mengikuti perkembangan trend market yang berkembang. 


\section{References}

Brahmana, R. K., You, H. W., \& Kontesa, M. (2020, June 28). Does Ceo Power Matter For The Performance Of Retrenchment Strategy? Journal Of Strategy And Management. Doi:Https://Doi.Org/10.1108/Jsma-10-2019-0186

Uppal, N. (2020, July 8). Mediating Effects Of Person-Environment Fit On The Relationship Between High-Performance Human Resource Practices And Firm Performance. International Journal Of Manpower. Doi:Https://Doi.Org/10.1108/Ijm-10-2019-0476

Wang, R., Lee, C. J., Hsu, S. C., \& Chen, J. H. (2020, August 23). Preventing Or Encouraging Illegal Activities By Construction Firms: Effects Of Top Management Team Compensation And Aspiration-Performance. Engineering, Construction And Architectural Management. Doi:Https://Doi.Org/10.1108/Ecam-08-2019-0440

Pratono, A.H. (2016) Strategic Orientation And Information Technological Turbulence: Contingency Perspective In Smes, Business Process Management Journal, 22(2), 368-382,

Pratono, Et Al. (2019), Achieving Sustainable Competitive Advantage Through Green Entrepreneurial Orientation And Market Orientation: The Role Of Inter-Organizational Learning. The Bottom Line, 32(1), 2-15

Homburg, C., Artz, M. And Wieseke, J. (2012), "Marketing Performance Measuremant Systems: Does Comprehensiveness Really Improve Performance?”, Journal Of Marketing, Vol. 76 No. 5, Pp. 5677.

Bradley, S., Wiklund, J. And Shepherd, D. (2011), "Swinging A Double-Edged Sword: The Effect Of Slack On Entrepreneurial Management And Growth”, Journal Of Business Venturing, Vol. 26 No. 5, Pp. 537-554

Zhang, J. And Duan, Y. (2010), "The Impact Of Different Types Of Market Orientation On Product Innovation Performance", Management Decision, Vol. 48 No. 6, Pp. 849-867.

Porter, M. (1998), Competitive Strategy: Technique For Analyzing Industries And Competitors, The Free Press, New York, Ny

Covin, J. And Lumpkin, G. (2011), “Entrepreneurial Orientation Theory And Research: Reflection On A Needed Construct", Entrepreneurship Theory And Practice, Vol. 35 No. 5, Pp. 855872.

Harris, J. And Bromiley, P. (2007), "Incentives To Cheat: The Influence Of Executive Compensation And Firm Performance On Financial Misrepresentation”, Organization Science, Vol. 18 No. 3, Pp. 350-367.

Delery, J.E. And Doty, D.H. (1996), "Modes Of Theorizing In Strategic Human Resource Management: Tests Of Universalistic, Contingency, And Configurational Performance Predictions", Academy Of Management Journal, Vol. 39, Pp. 802-835. 